\title{
THE NEW SILK ROAD: THE PROMISE AND THE CHALLENGE OF CHINESE EURASIAN INTEGRATION IN THE POST-SOVIET CENTRAL ASIA
}

\author{
Krzysztof Kozłowski \\ Warsaw School of Economics, Collegium of Socio-Economics \\ email: krzysiekkozlowski13@gmail.com
}

\begin{abstract}
The article discusses the New Silk Road Initiative in context of the Chinese Central Asian policies. An overview of the trajectory of development of the PRC political and economic presence will allow for an identification of the opportunities as well as the challenges to the future ambitions of the Middle Kingdom. The prospects of the New Silk Road are promising. The old problems - the lack of integration of Central Asian States and the economically challenging environment of the post-Soviet space - are still posing threats to every international political project in the region, though.
\end{abstract}

Keywords: People's Republic of China, the New Silk Road, Post-Soviet Central Asia, Xinjiang

\section{INTRODUCTION}

Chinese post-Soviet Central Asian policy is a great example of its gift for political consistency as well as its talent to swiftly adapt to dramatic international changes. Since 1991, the Middle Kingdom had to face two international challenges in the region. The first was the abrupt collapse of the Soviet Union. The rise of five post-soviet Central Asian states: Kazakhstan, Kyrgyzstan, Uzbekistan, Tajikistan and Turkmenistan, diametrically changed the political situation in the Chinese North Western neighborhood. It posed both an opportunity to expand into the previously Russian dominated region as well as a threat of proliferation of instability from fragile new states with weak, underdeveloped economies, challenging internal security situations and no international experience. The second challenge came with the American War on Terror and Western intervention in Afghanistan. Again suddenly, the regional security politics fundamentally changed as American and NATO forces were granted military bases in Uzbekistan and Kyrgyzstan, right at China's backdoor. Despite their indispensable character in the context of Afghan operations, for 
China they always posed a question concerning the true character of the American military presence in the direct vicinity of Chinese border.

The complex situation in post-Soviet Central Asia required strategic thinking from Beijing. It also provided a unique opportunity for the international community to witness the birth and the development from scratch of genuinely new Chinese political strategies. At the same time, as the post-Soviet Central Asian situation is closely connected with the situation of the Xinjiang Uighur Autonomous Region in China, where the indigenous population is ethnically closer to Central Asian Turkish counterparts than to Han Chinese, PRC foreign policy had to reflect the reality within PRC borders. The opening of Central Asia for other than Russian influences allowed to observe how Chinese power, in both regional and international contexts, develops strategic objectives, defines medium term goals, and deals with ongoing political problems. At the same time, the PRC's regional steps had to be consistent with the general Chinese approach to international relations. This turns the Chinese Post-Soviet Central Asian policy into a specific yet clear emanation of broader Chinese international relations' strategy.

Chinese rulers were basing their political approach toward the region on two fundamental rules. In the short and medium run, China was adapting itself to the existing balance of power in Central Asia. The assumption was straightforward yet very practical. If PRC got involved in security issues in the region it would mean confrontation with Moscow or Washington and reallocation of large political and economic potential needed elsewhere, especially in the booming Chinese economy. In the long run the PRC tried to develop a tight web of economic interconnections in the region. Again the reason was predominantly pragmatic. If it succeeded, the economic development should positively influence stability of the region, thus keeping the future costs of regional security low as well as eroding Russian and American influence, based largely on military strength. Thus, China was generally aiming to be a free rider as far as the security issues were concerned while at the same time slowly but steadily and consistently expanding in the field of regional economics.

Today the strategy undergoes a significant change, though. As Xi Jinping inaugurated the policy of development of the New Silk Road, designed to reconnect the Middle Kingdom with Europe via modern version of the ancient trans-Asian trade route, PRC the came out of the Russian and American shadow and took the regional center stage. The ambitious plans of economic integration of Asian states on the basis of economic cooperation backed up by PRC infrastructure investment plans opened a new chapter in contemporary Chinese political activity. However, the promise of a great future still faces pragmatic challenges of the present. Contrary to the earlier practical character of Chinese engagement in post-Soviet Central Asia, the recent declarations sound general and it's hard to evaluate their true content. It is also unclear how China will address the practical challenges that made Russian and American political endeavors in post-Soviet Central Asia less 
impressive than everyone expected. Despite alluring future perspectives, existing political reality and practice still pose questions with no obvious answers.

The primary goal of the article is to discuss the changes occurring in the region since the 1990's in the context of growing Chinese presence and the plans concerning the New Silk Road initiative ${ }^{1}$. It will be achieved by reconstructing the major features of the Chinese political strategy concerning regional and security challenges in the context of the so called New Great Game in post-Soviet Central Asia. The analysis of the trajectory of the development of Chinese policies will allow for a definition of the opportunities as well as the challenges to China's future ambitions. As far as the former are concerned, the prospects of pushing Asian development forward are promising. The New Silk Road, together with plans of establishing the Maritime Belt backed up by the Asian Infrastructure Investment Bank may become economic and political game changers in the whole of Asia. As far as the latter are concerned, they are far more numerous than many observers assume, though. The old problems - the lack of integration of Central Asian states dominated by patrimonial politics and the economically challenging environment of post-Soviet space - still pose threats to every international political project in the region. The question is, does PRC have a realistic plan or only impressive ambitions to tackle them?

\section{THE BEGINNINGS}

In eighteenth and nineteenth century Central Asia was dominated by civilization centers in Beijing and Moscow ${ }^{2}$. In twentieth century it became an arena of socialist modernization: Russian in five republics and Chinese in Xinjiang ${ }^{3}$. Since the middle of the century the role of the PRC and USSR seemed indisputable 4 . The creation of new five Post-Soviet states in 1991 opened a genuinely new chapter in the history of Central Asia.

From the Chinese perspective, the political situation in post-Soviet Central Asia in 1991 was very complex. The collapse of USSR and the rise of absolutely new political space on the Western flank of the Middle Kingdom required both an

1 In the Nineties of the $20^{\text {th }}$ century in A. Rashid's opinion China had no defined political strategy in Post-Soviet Central Asia. The study presents a different point of view. Compare: A. Rashid, The New Great Game - The Battle for Central Asia's Oil, "Far Eastern Economic Review", 10.04.1997; H.H. Karrar, The New Silk Road Diplomacy, UBC Press, Vancouver, Toronto 2009, pp. 75-77.

2 M. Dillon, Xinjiang: China's Muslim Far Northwest, Routledge Curzon, London 2004, pp. $66-67$.

3 D.C. Gladney, Responses to Chinese Rule: Patterns of Cooperation and Opposition, in: S. Starr, Xinjiang, China's Muslim Borderland, M.E. Sharpe, Armonk, New York 2004, pp. 375-378.

4 The political void after the collapse of USSR and resulting political window of opportunity for expansion in the region was seen as one of the major geostrategic issues in post Cold War reality of the 1990's in: Z. Brzeziński, The Grand Chessboard: American Primacy and Its Geostrategic Imperatives, Basic Books, New York 1997. 
immediate reaction and a long term policy. At first, China cautiously but steadily developed its presence in the region ${ }^{5}$. Chinese strategy was twofold. First, Beijing was investing in trust- and confidence-building activities with the new republics by bilaterally solving border disputes and developing closer economic relations. Second, it funded and strengthened a multilateral platform of contacts - the Shanghai Five, which later turned into Shanghai Cooperation Organization. Still, throughout the 1990's the PRC consistently kept a low profile to not create any undesired attention from Russia or the US about its growing influence in the neighboring region. The fact that it was almost unnoticed by the international community, including international relations' scholars (visible in absence of relevant academic research before 2001), confirms the success of the strategy. All later achievements of Chinese diplomacy were based on the foundations of the first decade of contacts with the region.

The approach gave the desired effects. Post-Soviet Central Asian republics engaged in economic and later political cooperation with $\mathrm{PRC}^{6}$. It is also symptomatic that the cooperation was crisis-free, while similar contacts with the US and Russia were not. Beijing did not enjoy local connections, like Russia, or global influence, like the US. However, the PRC, as an immediate neighbor of the region, cared not only about immediate gains but also about the long term development of stabile relations. Instability in Central Asia could cause instability in Xinjiang. One should not forget that any social tensions in Xinjiang may reach Tibet and echo in Taiwan. This makes the peaceful and stable development of post-soviet Central Asia an objective of not only foreign policy, but also an important issue for Chinese home affairs. In effect, the major difference between the policies of Beijing and the policies of Moscow and Washington is that position of the PRC was slowly but steadily strengthening, while the Russian and American positions were fluctuating. One can just mention consequences of the intervention in Afghanistan in the case of US and of the war with Georgia in the case of the Russian Federation. Even the global changes after September 11 did not prevent China from expanding in Central Asia. It seems that in the region the time was on the Chinese side ${ }^{7}$.

As far as the political situation in the region was concerned, the crucial moments from the PRC's point of view were the collapse of the USSR and September 11. The Soviet Union left behind five politically vulnerable, economically weak, autocratic

5 S. Feng, Chinese-Russian Strategic Relations: The Central Asian Angle, in: E. Wie Davis, R. Azizian, Islam, Oil and Geopolitics: Central Asia After September 11, Rowan and Littlefield, Lanham 2007, p. 204.

6 Z. Sun, Central Asia's Transition to a Market Economy: An Analytical Comparison with China, in: Y. Zhang, R. Azizian, Ethnic Challenges beyond the Borders: Chinese and Russian Perspectives on the Central Asian Conundrum, MacMillen Press, London 1998, pp. 150-153.

7 E.S. Medeiros, China's International Behavior: Activism, Opportunism and Diversification, RAND, Pittsburgh 2009, pp. 45-60. 
states. The ideological void was filled with a mixture of Islam and clan-tribal norms ${ }^{8}$. No less important were non-state actors, particularly those involved drug trafficking, and terrorist organizations in Afghanistan and Pakistan, potentially destabilizing the region ${ }^{9}$. The proximity of the war economy in Afghanistan to the underdeveloped economies of post-Soviet Central Asian states created the threat of the development of potentially radical movements, including paramilitary ones. The key issue for China was internal security in Xinjiang (diqu anquan ${ }^{10}$ ) endangered by Islamic extremism (yisilan jiduan zhuyi ${ }^{11}$ ), or ethnic problems in post-soviet states (minzu guanxi wenti ${ }^{12}$ ). Instability in Central Asia was perceived as dangerous because of its potentially negative influence on Xinjiang. It resulted in an emphasis on security issues in cooperation with Central Asian states in Chinese politics ${ }^{13}$.

The very first problem China had to address immediately was a potential resurrection of pan-Islamism and pan-Turkism in the area of the post-Soviet ideological void $^{14}$. Despite the fact that in the Eighties the ethnic and religious problems in Chinese Xinjiang seemed to be dormant, many Chinese observers were afraid that the tremors in Central Asia could awaken them again ${ }^{15}$. The PRC faced a question whether secular Central Asian regimes would be responsive to its fears concerning the political and social stability of its far West. It turned out that China had good grounds to be afraid. During the first half of the Nineties there were sporadic cases of agitation for the independence of Xinjiang. On the local level the popularity of Islam grew, visible in the increased number of mosques established, with or without the consent of the Xinjiang local administration. There were even cases of Chinese Communist Party members taking part in religious rituals ${ }^{16}$. Thus, persuading post-Soviet presidents in Central Asia not to help Uyghur case was

${ }^{8}$ A throughout analysis of internal situation of each post-soviet state of Central Asia may be fund in a series of monographs Wspótczesna Azja Centralna by T. Bodio (ed.).

${ }^{9}$ A throughout analysis of terrorist and criminal networks in Central Asia: S. Redo, Zwalczanie przestępczości w Azji Centralnej, Elipsa, Warszawa 2007.

${ }^{10}$ Y. Zhang, R. Azizian, Ethnic Challenges beyond the Borders: Chinese and Russian Perspectives on the Central Asian Conundrum, MacMillen Press, London 1998, pp. 147-165.

${ }^{11}$ On Chinese understanding of Islamic extremism: Z. Pan, Zhongnanya de minzu zongjiao chongtu [Religious and Political Conflicts in Southern and Central Asia], Xinjiang Renmin Chubanshe, Urumchi 2003.

${ }^{12}$ J. Li, Shi nian jubian (Ten Years of Great Change), Shufang chubanshe, Beijing 2003, pp. $117-144$.

${ }^{13}$ This has changed in 2001, since when PRC perceives Afghanistan and Pakistan as a source of potential threat for stability in Xinjiang rather than Post-Soviet Central Asia.

${ }^{14}$ G. Christoffersen, Xinjiang and the Great Islamic Circle: The Impact of Transformational Forces on Chinese Regional Economic Planning, "China Quarterly" No. 133, 1993, p. 142; K. Zhengling, Xinjiang: Opening Wider to the Outside World, "Bejing Review" 25.11.1991.

${ }^{15}$ N.R. Lardy, China and the Asian Contagion, "Foreign Affairs" No. 77 (4)/1998, pp. 78-88.

${ }^{16}$ H.H. Karrar, The New Silk Road ..., p. 7. 
the first regional Chinese success. There was hardly any official Uygur activity in post-soviet Central Asia after $1998^{17}$.

Economically China benefited a lot from the opening of new markets beyond its western border. This refers especially to Xinjiang, which is traditionally poorer than other parts of the PRC. Torn between Russia and China during republican times and underdeveloped under Mao's rule, it began to attract attention of Beijing after 1991. The most obvious example was cross-border trade. In 2008 foreign exchange between China and Central Asia, conducted almost entirely via via Xinjiang, went over $\$ 86$ billion and is still growing ${ }^{18}$. Its average 10\% growth rate was one of the highest in the entire $\mathrm{PRC}^{19}$. From the Chinese, still partly materialistic perspective, economic development should be beneficial for social peace and crucial in preventing separatist activity in the region or extremism in its close vicinity.

The Autonomous Region also benefited from increased the Chinese interest in energy resources. Rapidly growing demand for oil coupled with American presence in regions of the globe traditionally supplying China with black gold forced Beijing to diversify its sources of imports and to engage in the race for energy in Central Asia. The Kazakhstan-China oil and Turkmenistan-Uzbekistan-Kazakhstan-China gas pipelines are the best examples of this trend ${ }^{20}$. In the context of the militant approach of USA and of aggressive Russian policies, both in managing energy resources and in military sense, China seems to be a responsible and trustworthy partner with serious business plans about Central Asia. The impression is even stronger because cooperation with the PRC did not come combined with promotion of democracy, as in case of the US, or the glorification of post-Soviet heritage, as in case of Russia. The only form of Chinese political pressure on the five republics was the Uygur case. However, it was skillfully interwoven in regional strategy of combating terrorism, extremism and separatism, also used as an instrument of fighting political opposition of the autocratic regimes.

One may sum up that the PRC political rulers initially based their approach to the region on two fundamental assumptions. First, China was adapting itself to the existing balance of power in Central Asia. In this respect the goal was to exploit Russian and American involvement in maintaining regional security to minimize the costs of its own involvement in issues regarding regional stability. The logic was simple. If PRC got involved in security issues in Central Asia it would mean regional competition with the Russian Federation or the US. This would translate into undesired large political and economic engagement as China still had to invest

${ }^{17}$ M.B. Olcott, Islam and Fundamentalism in Independent Central Asia, in: R. Yaakov, Muslim Eurasia: Conflicting Legacies, Frank Cass, London 1995, p. 23.

${ }^{18}$ China Daily, Trade ties blossom as govt contacts increase, 15.06.2011, http://www.chinadaily.com.cn/cndy/2011-06/15/content_12697755.htm (access: 29.11.2015).

${ }^{19}$ Even in context of low level at the beginning of cooperation, what of course positively influence the overall dynamics of economic indicators, the mentioned growth is still impressive.

${ }^{20} \mathrm{~K}$. Kozłowski, Miejsce CHRL w międzynarodowej polityce energetycznej, Kwartalnik „Studia i Prace" Kolegium Ekonomiczno-Społecznego SGH, 2 (14)/2013, s. 1173-178. 
most of its assets into economic development. Second, China was keeping a low profile, and exploiting Russian and American involvement in regional security issues allowed PRC to develop a tight web of economic interconnections with the new post-Soviet states. Chinese elites assumed, that economic development should positively influence stability in Central Asia, thus keeping the future costs of regional security low and eroding the military influence of Russia and US.

It's crucial to notice that even despite temporary tensions between PRC and the US in 2005 and PRC and the Russian Federation in 2008, China did not perceive the situation purely in terms of a geopolitical competition or zero-sum game. Chinese politics were far more nuanced. Beijing did not try to limit Russian or American influence in general, but rather to limit opportunities for the US and Russian Federation to limit Chinese influence. On the one hand PRC, politicians strived for maximum freedom of political action. On the other hand, they wanted to take advantage of the US and Russian Federation presence as long as possible. American military presence in Afghanistan took a large burden from the shoulders of Beijing and Moscow. Understanding Russian regional sentiments allowed PRC to evade confrontation on social level with sovietized Central Asian political elites. PRC politicians understood that they could not and should not try to reach whatever goals they had at the expense of open conflict with Moscow or Washington. China was evaluating its own actions in the context of alternative ones that are not necessary because of American (for example, in Afghanistan and the Pakistani borderland) or Russian (for example, during the Nineties in Kyrgyzstan and Tajikistan) regional involvement. One should not forget that the legitimacy of the Communist Party depended, and still largely does, on providing socially expected effects in the economic realm. In that context, larger expenses on security issues in Central Asia or costs of rivalry with Russia or the US could have had disastrous consequences. Instead China was engaging in multilateral cooperation in the region to minimize the political and economic costs to its own security and in the future to create a situation when no increase of Chinese expenses in this field would be necessary. Chinese political elites simply understood, that the consequences of an American or Russian withdrawal might have been far more costly than their stay.

Such an approach to Central Asia is an interesting example of Chinese international policy in general. It is worth noticing, that from a broader perspective the above assumptions could be treated as a regional interpretation of a general Chinese political strategy in the international space. It's hard not to agree with M. Lanteigne, that "Beijing faces two unique barriers which prevent the country from taking the traditional paths of territorial expansion and political-economic domination in order develop as a great power. The first is the US and its inherent military and economic strength; the second is existence of nuclear weapons, which make direct great power conflict unacceptably costly" ${ }^{21}$. The Chinese solution

${ }^{21}$ M. Lanteigne, China and International Institutions, Alternative Paths to Global Power, Routledge, London, New York 2005, p. 8. 
after 1978 was to exploit the opportunities offered by the globalizing world to minimize costs of maintaining security and to channel the saved assets into modernization of the state. PRC based its future position on developing the economic potential and the vast web of economic relations which would make a conflict with the Middle Kingdom too costly to even consider. Central Asia is no exception. Throughout the 1990's and the first decade of the $21^{\text {st }}$ century China tended to concentrate its attention on economic growth and modernization in Xinjiang. To a large extent all Chinese administrations within this period approached international affairs as an opportunity to minimize expenditures concerning regional security by getting involved in multilateral cooperation. It is enough to notice that, apart from Shanghai Five and Shanghai Cooperation Organization, there was hardly any genuinely Chinese initiative in the field of international relations. In Central Asia, just like in the rest of the world, the PRC was generally adapting itself to the international reality rather than aiming to change it.

\section{THE NEW SILK ROAD}

As the first half of the second decade of the $21^{\text {st }}$ century passes by, Chinese policies seem to evolve and to show new, previously absent, and more ambitious features, though. As Beijing strengthens in economic and security dimensions, its international status rises. Chinese development seems to coincide with the weakening of Russian and American power. These changes make it less and less receptive to Moscow's or Washington's political preferences. PRC becomes more assertive and starts to think about developing regional plans alternative to the contemporary balance of power. Already now multilateral connections of Beijing make it more resistant to traditional bilateral forms of American and Russian political pressure.

The alleged first signals of changes in Chinese policy in Central Asia were heralded already in the first decade of the 21 st century. The joint Chinese-Russian calls for withdrawing American military from Central Asia in 2005 or Chinese opposition to Russian demands of SCO support in Georgian conflict in 2008 were often interpreted as signs of growing Chinese regional assertiveness ${ }^{22}$. However those diagnoses of rising Chinese resistance to Western rules in regional relations proved to be premature. The comments concerning the SCO summit in 2005 faded with no long term changes taking place. The Russian - Chinese diplomatic standoff in 2008 soon gave way to rejuvenation of political rapprochement on the basis of energy deals ${ }^{23}$. The world had to wait until 2013 to witness a true

${ }^{22}$ K. Kozłowski, Państwo Środka a Nowy Jedwabny Szlak. Poradziecka Azja Centralna i Xinjiang w polityce CHRL, Wydawnictwo Adam Marszałek, Torun 2011, pp. 204-221.

${ }^{23}$ K. Kozłowski Geopolityka naftowa Chińskiej Republiki Ludowej, Wydawnictwo Adam Marszałek, Toruń 2013, pp. 145-162. 
declaration of political change in Chinese foreign policy toward the region. It came with presenting the New Silk Road Concept.

On September $7^{\text {th }}, 2013$, in Kazakhstan President Xi Jinping presented the first version of the Chinese New Silk Road: a vast network of railways, oil and gas pipelines, highways and streamlined border crossings both westward - through the former Soviet republics, and southward - toward Pakistan, India, and the rest of Southeast Asia. Together with the Maritime Belt, declared the very same year in Indonesia, the new infrastructure is meant to "break the bottleneck in Asian connectivity" 24 . In 2015 the innovative character of the idea was supplemented with plans, and eventually funding, of the Asian Infrastructure Investment Bank meant to finance the bold Chinese endeavors. The so called "One Belt, One Road" incorporates increased diplomatic coordination, development of a network of trade facilities, free trade zones and other trade facilitation policies, financial integration and increased people-to-people contacts throughout nations in Asia, Europe, the Middle East, and Africa. The network is also meant to expand the international use of Chinese currency in transactions throughout Eurasia ${ }^{25}$. If successful, the ambitious program can turn China into a central economic and diplomatic force in Eurasia. Evidently the New Silk Road draws from calls by Chinese academics to actively respond to the United States' pivot to $\mathrm{Asia}^{26}$. Chinese newspapers called it "the most significant and far-reaching project the nation has ever put forward" 27 . Some observers have even characterized it as China's Marshall Plan ${ }^{28}$. However, from the perspective of Beijing the initiative is meant not to divide but to integrate Eurasia by focusing on economic growth rather than political influence.

The New Silk Road is meant to advance several goals aligned with Xi Jinping's broader aim of national rejuvenation. First and foremost, as it is planned to link China, Central Asia, the Middle East, Europe and Russia, the New Silk Road is to provide an outlet for excess industrial capacity. As the new Chinese norm becomes the reality of the PRC economy, Beijing needs to cool an over-

${ }^{24}$ The Asian Development Bank, highlighting the need for more such investments, estimates that the region faces a yearly infrastructure financing shortfall of nearly $\$ 800$ billion. J. McBride, Building the New Silk Road, Council on Foreign Relations Backgrounders, 25.05.2015, http:// www.cfr.org/asia-and-pacific/building-new-silk-road/p36573 (access: 29.11.2015).

${ }^{25}$ President Xi Jinping subsequently announced plans for the maritime silk road at the 2013 summit of the Association of Southeast Asian Nations (ASEAN) in Indonesia. To accommodate expanding maritime trade traffic, China will invest in port development throughout the Indian Ocean, in Bangladesh, Sri Lanka, the Maldives and Pakistan.

${ }^{26}$ Y. Sun, March West: China's Response to the U.S. Rebalancing, brookings.edu, 31.01.2013, http://www.brookings.edu/blogs/up-front/posts/2013/01/31-china-us-sun (access: 29.11.2015).

${ }^{27}$ South China Morning Post, 'One belt, one road' initiative will define China's role as a world leader, 02.04.2015, http://www.scmp.com/comment/insight-opinion/article/1753773/ one-belt-one-road-initiative-will-define-chinas-role-world (access: 19.11.2015).

${ }^{28}$ Chinese government opposes such a view. C. Mengwei, Chinese FM says 'Belt and Road' initiatives not Marshall Plan, China Daily, 08.03.2015, http://www.chinadaily.com.cn/china/2015twosession/2015-03/08/content_19750300.htm (access: 29.11.2015). 
heated domestic infrastructure sector without substantially raising unemployment. Taking into consideration the vast infrastructural needs in Central Asia, the New Silk Road gives an opportunity to partly channel it abroad. The scale of planned enterprises will certainly create opportunities to benefit from trade and currency swaps, thus reinforcing the renminbi as a global currency. Securing energy deals will help secure supplies as China's energy demand continues to rise. The geopolitical factors within China's borders allow aligning the strategy with further development of western and southern Chinese regions in terms of growth and employment as well as managing ethnic unrest. It is also important to notice who is put in the center of Chinese attention. The PRC is evidently perceiving Asia's developing economies as sources of future growth as the developed world's growth remains sluggish. The plans will certainly expand Beijing's ties to major developing countries, and build support for a reshaped international system, probably putting China at the center of the world stage. "Strengthened bilateral ties with nations along the dual trade routes will support China's ambitions to build a network of non-Western international organizations in which China plays the main, if not dominant, role" ${ }^{29}$. According to many observers, the success of the New Silk Road would allow China to pursue international diplomatic primacy outside of Beijing's relationship with Washington ${ }^{30}$.

The fact that the New Silk Road became a hot topic of political and academic discussions does not go in par with discovering its contents, though. Since 2013 the details of the New Silk Road vary by proposal to proposal. On one hand it seems to be gaining momentum. The plans have strong financial backing, particularly through AIIB. They also enjoy the seemingly unquestioned support of China's political and economic elites. On the other hand, the euphoria and enthusiasm should not obscure the obstacles that could challenge China's ability to realize its ambitions. And these concern not just the broader range of problems PRC will have to deal with. The new strategy will require new instruments and approaches, that China has not yet had the opportunity to try out.

First, the financing standards concerning the New Silk Road could undermine the strategy's progress. Of course, no one would object to the plan to fill Asia's infrastructure gap, estimated around $\$ 8$ trillion through $2020^{31}$. However, taking into consideration the lack of transparency of infrastructure financing methods within China and a tendency to support economically unfeasible development projects, reproducing similar patterns within the New Silk Road framework may jeopardize

${ }^{29}$ J. Stokes, China's Road Rules: Beijing Looks West Toward Eurasian Integration, "Foreign Affairs", 19.04.2015, https://www.foreignaffairs.com/articles/asia/2015-04-19/chinas-road-rules (access: 29.11.2015).

${ }^{30}$ J.M. Smith, Beware China's Grand Strategy: How Obama Can Set the Right Red Lines, "Foreign Affairs", 20.05.2015, https://www.foreignaffairs.com/articles/china/2015-05-20/beware-chinas-grand-strategy (access: 29.11.2015).

${ }^{31}$ The Economist, Why China is creating a new "World Bank" for Asia, 11.11.2014, http:// www.economist.com/blogs/economist-explains/2014/11/economist-explains-6 (access: 29.11.2015). 
the Chinese investment plans $\mathrm{s}^{32}$. One should not forget, that if the goal is to cool down the infrastructure sector at home, the opportunities to dynamically expand abroad may be counterproductive. In addition, Chinese infrastructure projects may produce unexpected environmental or human rights developments if Chinese enterprises follow patterns they have enacted many times enacted at home.

Second, the above observations make the purely economic character of the New Silk Road impossible. Such a large scale plan sooner or later will become a tool of regional geopolitics. Thus, it will require Beijing to manage great power competition within Central Asia, South Asia and the Middle East no longer as a free rider but as a major actor in the international political game. It is enough to state, that even though Chinese-Russian relations are getting better, Russia's Eurasian Union plans, linking former Soviet states through economic cooperation, pose direct competition to China's Eurasian integration strategy. India's reservations about Chinese regional aspirations will also be natural, since Chinese actions may compete with Indian "Act East" and "Connect Central Asia" policies. The vast scale of Chinese plans will certainly test Beijing's ability to balance competition with cooperation - working with, rather than against, neighbors and global political powers.

Third, within the above mentioned context one should not only concentrate on major powers. The success of the New Silk Road policy will depend on cooperation with regional and local Eurasian leaders - a goal not yet achieved in the long run by any global actor. Especially in Central Asia and the Middle East, local regimes draw from centuries of experience playing foreign powers off one another to gain political and financial advantage ${ }^{33}$. As J. Stokes notes "amid intensifying sectarian conflict in the Middle East, for example, Chinese leaders are likely to find it increasingly difficult to balance China's longstanding ties with Iran and burgeoning relations with Sunni states, led by Saudi Arabia" ${ }^{34}$. The post-Soviet Central Asian countries are no different, as the history of military bases in Uzbekistan and Kyrgyzstan shows ${ }^{35}$. This, combined with challenges posed by non-state actors creates a dimension of Eurasian politics that China is not yet accustomed to.

All these observations point to one questionable element within Chinese Eurasian strategies. Until 2013 they were based on the assumption of sitting in the back seat of regional politics while taking advantage of the New Great Game developments and not allowing them to hinder Chinese interests. The New Silk

${ }^{32}$ The infamous "ghost cities" being the best example. More on internal contradictions of the Chinese financial system: C.E. Walter, F.J.T. Howie, Red Capitalism: The Fragile Financial Foundation of China's Extraordinary Rise, Wiley, Singapore 2011.

${ }^{33}$ This practice worked in Central Asia before 2013, though. K. Kozłowski Post-Soviet Central Asia in People's Republic of China's Politics, in: T. Stępniewski (ed.), The New Great Game in Central Asia, Instytut Europy Środkowo-Wschodniej, Wydawnictwo KUL, Lublin 2012.

${ }^{34}$ J. Stokes, China's Road Rules...

${ }^{35}$ A. Cooley, Great Games, Local Rules: The New Great Power Contest in Central Asia, Oxford University Press, Oxford 2012, pp. 116-161. 
Road plans seem to outgrow this pattern but do not introduce new approaches other than the bigger scale of the instruments used previously. The ambitious vision of Eurasian integration could stretch China's foreign policy doctrines and capabilities to a breaking point. China's politics based on promoting win-win outcomes, consensus based decision-making, and avoiding interference into internal political affairs will be tested by the reality of contradictory interests of its foreign partners as well as by the potential need to assist Chinese investments and enterprises abroad. If such circumstances arise, it is easy to imagine Chinese actions going beyond the basic protection of its investments into broader geopolitical actions. The developments in the South China Sea should make every observer skeptical about China's ability to manage such situations smoothly. So far, Chinese efforts to be perceived as a responsible stakeholder in international politics have struggled to go beyond ambitious symbolism. While China has proven to be effective in small scale engagement with Central Asia, it could be overreaching politically while seeking out to deepen its presence in Eurasia. As a result, it risks being drawn into conflicts it is yet not ready to face.

\section{CONCLUSIONS}

The Chinese New Silk Road is one of the most important international projects in the second decade of the $21^{\text {st }}$ century. If successful it may change the economic and political reality of the whole continent. Together with plans of establishing a Maritime Belt, it may turn the PRC into a truly Middle Kingdom of Eurasia. Ambitious, bold and transformative - these are the adjectives most often used in Chinese papers to describe it.

After a closer look, though, it is hard not to ask questions how the plans will work in reality. With funding provided and political backup ready in Beijing, the Chinese authorities seem to be confident of success. However, the regional experiences of US and Russian Federation in post-Soviet Central Asia as well as the earlier nature of Chinese presence there should make everyone wary of potential obstacles on the New Silk Road. The US and Russia did not manage to project their power in the region as they planned. Washington was incapable of establishing a permanent foothold in the region. Moscow is still struggling to reintegrate the former Soviet space, with no clear evidence of success ${ }^{36}$. The Chinese strategy throughout the first two decades of Central Asian independence was based on limiting its ambitions and staying second in line in local political games. Taking the lead requires new instruments and innovative approaches, but China seems to be relying on a simple increase of economic presence. Despite ambitious statements, this may be too little to transform the Central Asian reality.

${ }^{36}$ G.J. Ikenberry, The Illusion of Geopolitics, "Foreign Affairs", vol. 93, 3/2014, pp. 80-90. 
China has proven capable of achieving ambitious tasks. However, Central Asia has also proved to be resistant to transformative attempts. Translating the New Silk Road initiative from an ambitious cartographic blueprint into a working economic and geopolitical strategy will test China's capabilities across all aspects of foreign policy. Regardless how promising the Chinese plans sound, one should wait to judge their true effects rather than being seduced by the allure of a promising but uncertain future.

\title{
NOWY JEDWABY SZLAK: SZANSE I ZAGROŻENIA DLA \\ CHIŃSKO-EUROATLANTYCKEJ INTEGRACJI NA OSZARZE POSTSOWIECKIEJ \\ AZJI CENTRALNEJ
}

\begin{abstract}
Abstrakt. Artykuł dotyczy oceny szans powodzenia strategii Nowego Jedwabnego Szlaku w kontekście relacji Chińskiej Republiki Ludowej z państwami poradzieckiej Azji Centralnej. Bliższe spojrzenie na trajektorię wzrostu chińskiej obecności gospodarczej i politycznej w regionie pozwala zdefiniować sznse jak i wyzwania jakie stoją przed Państwem Środka. Perepektywy Nowego Jedwabnego Szlaku są obiecujące. Stare problemy, jak brak integracji poradzieckiej Azji Centralnej, czy gospodarczo trudne środowisko obszaru poradzieckiego - wciąż jednak stanowią realne zagrożenie dla każdeo projektu politycznego w tej części świata.
\end{abstract}

Słowa kluczowe: Chińska Republika Ludowa, Nowy Szlak Jedwabny, Azja Centralna, Xinjiang, obszar postradziecki 